\title{
LIONS: een nieuw financieel produkt?
}

\author{
Drs. P.P.M. Smid en Drs. M. Smink
}

\section{Inleiding ${ }^{1}$}

Het financiële systeem is voortdurend aan veranderingen onderhevig. Algemeen gesteld zijn oorzaken voor deze veranderingen met name terug te voeren op ontwikkelingen in de operationele efficiëntie van dit financiële systeem. Deze efficiëntie wordt o.a. bepaald door de omvang van transactiekosten, verschillen in belastingheffing voor verschillende groepen marktparticipanten, de beschikbaarheid van financiële instrumenten met een eigen karakteristieke betalingsstructuur (de zogenoemde marktcompleetheid), en de mate waarin financiële informatie beschikbaar is voor verschillende marktpartijen. ${ }^{2}$ Een belangrijke categorie van veranderingen in het financiële systeem is die van de financiële produktinnovaties.

Onder financiële produktinnovatie zullen we hier verstaan: het succesvol introduceren van een nieuw soort vermogenstitel op de financiële markt. Met nieuw doelen wij hier met name op de betalingsstructuur van de vermogenstitel. ${ }^{3}$ De afgelopen decennia is gebleken dat er veelvuldig financiële produktinnovaties zijn opgetreden. Ook in Nederland waar, vooral in de jaren tachtig, vele nieuwe financierings- en beleggingsinstrumenten hun weg naar de vermogensmarkt vonden. Zo is in 1987 een nieuw financieel produkt verschenen:

de Leveraged Income Obligation via New Shares, LIONS, uitgegeven door Assurantieconcern Stad Rotterdam anno 1720 N.V. (in het vervolg van dit artikel veelal afgekort als
SR). De LIONS is een obligatie met als bijzonder kenmerk dat de jaarlijkse rente wordt voldaan in de vorm van aandelen (dat wil zeggen: certificaten van aandelen) van de emitterende onderneming. Hiermee vormt de LIONS een hybride financieringsinstrument: een tussenvorm van vreemd en eigen vermogen. ${ }^{4}$ De onderhavige LIONS van SR hebben een looptijd van 10 jaar en zijn sinds de uitgifte in 1987 genoteerd aan de Amsterdamse Effectenbeurs. Overigens zij vermeld dat er na de uitgifte van de LIONS door SR op de Nederlandse vermogensmarkt tot op heden geen soortgelijke lening meer is geplaatst.

In dit artikel wordt nader ingegaan op deze produktinnovatie. In paragraaf 1 worden de eigenschappen van de LIONS van SR nader toegelicht. Tevens zal in deze paragraaf worden ingegaan op de motieven welke voor SR kunnen hebben gegolden om tot de uitgifte over te gaan. Daarna wordt in paragraaf 2 een financiële analyse uitgevoerd die uitmondt in de theoretische waardering bij de uitgifte. Hierbij wordt in het bijzonder aandacht geschonken aan de belastingpositie van de belegger. Paragraaf 3 maakt een verdere vergelijking tussen enerzijds het theoretische koersverloop

Drs. P.P.M. Smid is universitair docent Ondermemingsfinanciering aan de Faculteit der Economische Wetenschappen van de Rijksuniversiteit Groningen (vakgroep Bedrijfseconomie).

Drs. M. Smink is assistent in opleiding (AlO) aan de Faculteit der Economische Wetenschappen van de Rijksuniversiteit Groningen (vakgroep Bedrijfseconomie), werkzaam aan een dissertatie over asset liability management. 


\section{MAB}

en anderzijds het werkelijke koersverloop, gedurende het tijdvak 1987-1992. In de afsluitende paragraaf 4 komen de conclusies en additionele bespiegelingen aan de orde.

\section{De LIONS}

\subsection{Beschrijving}

Zoals reeds in de inleiding is opgemerkt vormt de LIONS een instrument met kenmerken van zowel vreemd als eigen vermogen.

Het vreemd vermogen karakter wordt bepaald door een zero-coupon obligatielening met een looptijd van 10 jaar. Deze obligatielening is groot nominaal $f 150$ miljoen en is verdeeld in CF-stukken aan toonder van nominaal $f 2000$,en van nominaal $50 \times f 2000,-{ }^{5}$ De uitgifte was a pari en de hoofdsom zal op 15 januari 1997 in haar geheel a pari worden afgelost; vervroegde gehele of gedeeltelijke aflossing is niet toegestaan.

Het eigen vermogen karakter wordt veroorzaakt door de wijze van rentebetaling op de LIONS. De LIONS geeft jaarlijks op 15 januari het recht op het verkrijgen van een nader bepaald nominaal bedrag aan certificaten van gewone aandelen Stad Rotterdam (zie onderstaand). Op 15 januari 1997 wordt, naast de hoofdsom, een nominaal bedrag aan certificaten SR ter grootte van twee maal de op dat moment geldende jaaruitkering verstrekt.

Ten tijde van de emissie is de jaaruitkering in certificaten vastgesteld op $f$ 10,- nominaal; de nominale waarde van een certificaat bedroeg toen eveneens $f$ 10,-- Deze jaaruitkering wordt jaarlijks aangepast aan de eventueel opgetreden kapitaalverwatering ten gevolge van de uitgifte van certificaten (al dan niet in de vorm van, bijvoorbeeld, stock-dividend). ${ }^{6}$ In de afgelopen 6 jaren bedroeg de aanpassing aan kapitaalverwatering gemiddeld ongeveer $1 \%$ per jaar: op 15 januari 1993 bedroeg de jaaruitkering $f$ 10,58 nominaal. Ten gevolge van een aandelensplitsing bedraagt sinds 1989 de nominale waarde per certificaat $f 2,50$. Onder de huidige omstandigheden worden jaarlijks dus 4,232 certificaten SR op de LIONS verstrekt.

Met betrekking tot de fiscale behandeling van de LIONS is het volgende relevant. Bij de belegger worden de verstrekte aandelen als inkomsten in natura beschouwd en als zodanig in aanmerking genomen naar de waarde in het economisch verkeer op het genietingsmoment: de marktwaarde. Eventuele winsten of verliezen op de hoofdsom worden als vermogensmutaties beschouwd en zijn dientengevolge niet belastbaar. Daar staat tegenover dat SR tot op het moment van schrijven van dit artikel (oktober 1993) nog steeds geen overeenstemming met de fiscale autoriteiten heeft kunnen bereiken over de fiscale status van de op een LIONS te verstrekken certificaten. Daar waar de belegger de marktwaarde van de certificaten als inkomen moet opgeven is de fiscale aftrekbaarheid voor SR (en dus voor potentiële nieuwe emittenten van LIONS-leningen) nog steeds niet zeker.

\subsection{Motieven voor uitgifte}

In het nu volgende zullen we ingaan op de motieven die een rol kunnen hebben gespeeld bij de introductie van de LIONS. Hierbij spelen twee elementen een rol. Enerzijds is het mogelijk dat er, door middel van de uitgifte van de LIONS, op een concrete behoefte van de zijde van SR als emittent wordt ingespeeld. Anderzijds dienen, voor een succesvolle innovatie, voldoende nieuwe elementen aanwezig te zijn die positief kunnen bijdragen aan de operationele efficiëntie van de vermogensmarkt. Meer in het bijzonder zullen met name één of meer van de volgende effecten moeten optreden (zie bijvoorbeeld Silber [1983], Van Horne [1985], Finnerty [1988] en Merton [1992])

- vermindering van transactiekosten;

- belastingvoordelen voor bepaalde marktpartijen:

vergroting van de marktcompleetheid;

- vermindering van belangentegenstellingen, zogenoemde agency conflicten, welke het 
gevolg kunnen zijn van verschillen in beschikbaarheid van informatie;

- vermindering van de gevolgen van macroeconomische onzekerheden (in het bijzonder kan dan worden gedacht aan de valuta-, inflatie- en renteproblematiek);

- vermindering van de negatieve gevolgen van bepaalde vormen van regelgeving;

- afname van bij marktparticipanten aanwezige knellende beperkingen.

Voor SR als emittent (en voor eventuele andere emittenten) zijn in verband met de uitgifte van een LIONS met name de volgende aspecten relevant. De onderneming heeft geen rentelasten op deze obligaties hetgeen de liquiditeit vergroot. Midden jaren ' 80 was in vergelijking met de concurrentie de liquiditeitspositie van SR minder sterk. Misschien heeft SR deze interne financiële situatie als knellend ervaren hetgeen mede de uitgifte van de LIONS-lening heeft uitgelokt. ${ }^{7}$ Door de geleidelijke groei van het eigen vermogen (ten gevolge van de jaarlijkse uitkering van certificaten) verbetert de solvabiliteitspositie (in overigens geringe mate), vindt slechts een geleidelijke verwatering van het eigen vermogen plaats en worden emissiekosten bespaard. ${ }^{8}$ Met dit laatste treedt, bekeken vanuit het perspectief van de theorie betreffende financiële markten, een operationeel efficiëntievoordeel op in de vorm van verminderde transactiekosten.

Met betrekking tot de vernieuwende elementen van de LIONS merken we verder het volgende op. Op het moment van uitgifte waren er op de Nederlandse kapitaalmarkt nog geen zero-coupon obligaties beschikbaar. Als zodanig was de LIONS mogelijk voor bepaalde marktpartijen aantrekkelijk. (Inmiddels zijn wel zero-coupon leningen verschenen). Ook is het denkbaar dat de specifieke betalingsstructuur van de LIONS aantrekkelijk is voor bepaalde categorieën beleggers, en dat er tot op zekere hoogte sprake is van optimal security design (zie Allen en Gale [1989]). Enerzijds voor particuliere beleggers die hiermee een ge- wenste combinatie van een aandelen- en obligatiebelegging kunnen bereiken, anderzijds mogelijk voor instituten vanuit met name een statutair gezichtspunt.

Mogelijk is ook de fiscale behandeling van de LIONS een overweging geweest voor introductie. Enerzijds kan hierbij de gedachte een rol hebben gespeeld dat er voor SR als emittent een aantrekkelijke regeling met de fiscus viel te treffen. Zoals eerder al opgemerkt bestaat hierover echter op dit moment geen duidelijkheid. Voorts kunnen overwegingen met betrekking tot zogenoemde fiscale cliëntèles een rol hebben gespeeld bij het structureren van de LIONS (zie bijvoorbeeld Dybvig en Ross [1986] en Dammond en Green [1987]). Hiertoe dient de nieuwe vermogenstitel te beschikken over een, voor een bepaalde groep potentiële beleggers, aantrekkelijk fiscaal ontwerp. Dit lijkt op het eerste gezicht hier niet het geval, daar de uit te keren certificaten, naar analogie met rentebetalingen, fiscaal worden belast.

De LIONS kan tevens zorgdragen voor een vermindering van bepaalde vormen van agency-kosten. ${ }^{9}$ Net als bij een converteerbare obligatielening kan de plaatsing van een LIONS-lening bijvoorbeeld leiden tot een vermindering van het risk incentive probleem. Overigens dient in dit verband te worden opgemerkt dat agency-kosten vooral relevant worden als een onderneming er slecht voor staat. Dit laatste lijkt voor SR (een verzekeringsmaatschappij en onder toezicht van de Verzekeringskamer) niet het geval.

Al met al lijkt de toegevoegde waarde van de LIONS als nieuw financieel instrument vanuit financieel-economisch perspectief bezien nogal betrekkelijk. De aantrekkelijkheid voor de belegger zal dan ook met name afhangen van, en moeten blijken uit, de prijsvorming van het instrument. Hierop zal in de volgende paragraaf worden ingegaan. 


\section{MAB}

\section{Theoretische waardering}

In deze paragraaf zal de theoretische waardering van de LIONS van Stad Rotterdam aan de orde komen. Deze theoretische waardering is gebaseerd op de arbitrage-gedachte. Daarbij staat de mogelijkheid tot het repliceren van de betalingsstructuur van de LIONS centraal

Door combinatie van elders op de vermogensmarkt aanwezige vermogenstitels wordt een betalingsstructuur gecreëerd die (vrijwel) identiek is aan die van de LIONS. ${ }^{10}$ De marktprijs van de LIONS zal dan ook worden afgezet tegen de waarde van de replicatie-portefeuille met vrijwel identieke gevolgen. Hiertoe zullen we eerst de LIONS ontleden in de basiscomponenten. De navolgende analyse maakt tevens duidelijk waarom wij voor deze 'indirecte' arbitage-redenering hebben gekozen.

\subsection{Analytische structuur}

Met de aankoop van een LIONS verwerft een belegger zich het volgende:

- een zero-coupon obligatie van nominaal $f 2000,-$;

- een serie termijncontracten op certificaten van aandelen SR.

Met betrekking tot de termijncontracten kan worden geconstateerd dat de termijnprijs impliciet bij vooruitbetaling, dat wil zeggen bij aankoop van de LIONS, wordt voldaan. De certificaten worden op de diverse coupondata immers om niet verstrekt! Ter verfijning betekent dit, dat de waarde van een LIONS bij uitgifte uit de volgende componenten bestaat:

1 de waarde van een zero-coupon obligatie van nominaal $f$ 2000,-;

2 de contante waarde van een in de toekomst te verstrekken serie certificaten van aandelen SR. Deze contante waarde is gelijk aan de totale huidige waarde van de te verkrijgen certificaten, exclusief de contante waarde van de niet meegekochte dividendrechten. ${ }^{11}$
In figuur 1 wordt de bepaling van de contante waarde van de serie termijncontracten toegelicht aan de hand van een voorbeeld. Daarin wordt de theoretische waarde bepaald van een portefeuille bestaande uit 4 termijncontracten, elk betrekking hebbende op een certificaat van aandeel, en met een termijnprijs van nihil

Figuur 1: Voorbeeld waarde termijncontracten

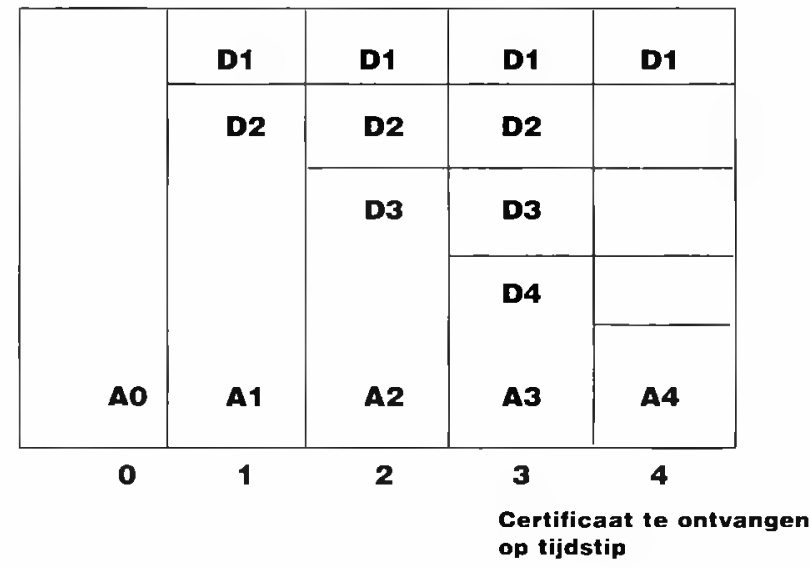

De contante waarde (op tijdstip $t=0$ ) van een serie van 4 termijncontracten op certificaten van aandelen is gelijk aan $A_{1}+A_{2}+A_{3}+A_{4}\left(A_{t}\right.$ is de contante waarde van een op tijdstip t te ontvangen certificaat). Deze kan worden gezien als de huidige (markt-)waarde van de te verstrekken certificaten, exclusief de contante waarde van de niet meegekochte dividendrechten. Dat is gelijk aan 4 keer de huidige aandelenprijs $\left(4 . A_{0}\right)$, minus $\left(4 . D_{1}+3 . D_{2}+\right.$ 2. $\left.\mathrm{D}_{3}+\mathrm{D}_{4}\right)$. $\mathrm{D}_{1}$ symboliseert de contante waarde van de gedurende jaar t per certificaat te ontvangen dividenden. Ofwel:

$A_{1}+A_{2}+A_{3}+A_{4}=4 \cdot A_{0}-4 \cdot D_{1}-3 \cdot D_{2}-2 \cdot D_{3}-D_{4}{ }^{12}$

\subsection{Rentegevoeligheid}

Met behulp van de analyse in paragraaf 2.1 kan ook het risico-profiel van de LIONS nader worden beschouwd; met name in verband met de gevoeligheid van de waarde van de LIONS voor wijzigingen in de rentevoet. Wij drukken daartoe de rentegevoeligheid van de LIONS 
uit in de gebruikelijke duration maatstaf. Indien eenvoudigheidshalve wordt uitgegaan van de veronderstelling dat een rentewijziging geen invloed heeft op de marktprijs van de certificaten van aandelen volgt dat de duration van de LIONS gelijk is aan de waardegewogen duration van het zero-coupon deel. Dit houdt in dat de duration van de LIONS gelijk is aan de looptijd van de zero-coupon vermenigvuldigd met het (waardegewogen) procentuele gewicht dat de zero-coupon in de waarde van de LIONS vertegenwoordigt.

Dus indien de waarde van de zero-coupon bij uitgifte a pari $53 \%$ van de waarde van de LIONS zou vertegenwoordigen, is bij een marktrente van $6,5 \%$ de duration van de LIONS ongeveer 5 . Bij een wijziging in de marktrente van $0,5 \%$ verandert de waarde van de LIONS met ongeveer $2,5 \%$. Ter vergelijking: een gewone obligatie met een resterende looptijd van 10 jaar en een coupon van $6,5 \%$ (terwijl de marktrente ook $6,5 \%$ is) daalt ongeveer $3,5 \%$ in waarde bij een rentestijging van $0,5 \%$ (de duration is ongeveer gelijk aan 7). ${ }^{13}$

Uit het voorgaande volgt tevens dat een LIONS, naarmate de looptijd verstrijkt, steeds meer het karakter van een zero-coupon lening krijgt omdat het aandelendeel (de contante waarde van de nog te verkrijgen certificaten) relatief steeds kleiner wordt; de koersvolatiliteit van de LIONS zal dan ook afnemen.

Op basis van de voorgaande uiteenzettingen zullen wij vervolgens pogen een theoretische waardering van de LIONS te geven, te weten bij de uitgifte (20 januari 1987). Omdat de fiscale status van de belegger van essentieel belang is voor die waardebepaling zal de waarde worden bezien vanuit de optiek van een belegger die niet belastingplichtig is (bijvoorbeeld een pensioenfonds) en van een particuliere belegger op wie het hoogste marginale belastingtarief van toepassing is (het tarief is op $60 \%$ gesteld). ${ }^{14}$

\subsection{Theoretische waarde bij uitgifte}

Aangezien in 1987 de nominale waarde van een certificaat van aandeel SR $f$ 10,- was en de vastgestelde jaaruitkering $f$ 10,- nominaal, zou volgens de in het prospectus vermelde voorwaarden jaarlijks minimaal 1 certificaat worden ontvangen. De in het prospectus gegeven aanpassingsformule voor kapitaalverwatering (zie ook noot 6) en de gegevens met betrekking tot kapitaalverwatering uit het verleden (deze bedroeg ongeveer 1\% per jaar) leiden tot een verwachte jaarlijkse opwaartse aanpassing van deze nominale uitkering. De omvang van deze aanpassing was uiteraard op voorhand niet met zekerheid bekend. Teneinde inzicht te verkrijgen in de mogelijke effecten van toekomstige kapitaalverwatering worden in het navolgende steeds drie alternatieve berekeningen gemaakt: één zonder aanpassing voor verwatering, één met $1 \%$ aanpassing en één met $2 \%$ aanpassing. Toename van kapitaalverwatering leidt, ceteris paribus, tot een stijging van de theoretische waarde van de LIONS omdat dan de nominale waarde van de jaaruitkering stijgt. ${ }^{15}$ Deze analysewijze leidt uiteraard tot scenario afhankelijke 'theoretische (contante) waarden' van de LIONS; de geplaatste aanhalingstekens geven aan dat dit theoretisch beschouwd niet gehee juist is. Per definitie heeft een contante waarde namelijk het karakter van een zekerheidsequivalent. ${ }^{16}$ Principieel bezien zou met een verwachte kapitaalverwatering dienen te worden gewerkt. Alle onzekerheden dienen te worden verwerkt in de te hanteren disconteringsvoet(-en) door middel van het gebruik van risico-opslagen. Dat geldt tevens voor de bepaling van de contante waarde van de niet meegekochte dividendrechten (als onderdeel van de theoretische waarde van de LIONS) De contante waarde van de niet meegekochte dividendrechten is onder meer afhankelijk van de volgende factoren:

- de ontwikkeling van het toekomstig te verstrekken dividend per aandeel;

de verwachte aanpassing aan de toekomstige kapitaalverwatering;

Conceptueel gezien zou de hieruit voortvloeiende onzekerheid dus ook dienen te worden verwerkt in de te hanteren disconteringsvoet(en). 
Zoals bekend brengt het bepalen van dergelijke disconteringsvoeten grote (schattings-)problemen met zich mee. Teneinde het expliciet schatten van de (groeivoet van de) dividenden en daarmee de disconteringsvoeten te vermijden, is gekozen voor een scenariobenadering waarbij de disconteringsvoet is gehanteerd die ook voor het zero-COupon deel is gebruikt.

Daar komt nog bij dat het gebruik van een disconteringsvoet waarin de 'juiste' risico-opslag wel is verwerkt zou hebben geleid tot een verlaging van de 'contante waarde' van de niet meegekochte dividendrechten en dus tot een verhoging van de 'theoretische waarde' van de LIONS. De in paragraaf 2.3.1 en paragraaf 3 weergegeven resultaten geven aan dat, in het geval er geen sprake is van belastingheffing, de marktprijs van de LIONS gedurende een groot deel van de looptijd onder de scenarioafhankelijke 'theoretische waarde' ligt. Een verhoging van de disconteringsvoet leidt daarmee tot een toename van de geconstateerde afwijking.

De inschrijving op de LIONS stond open tot woensdag 21 januari 1987, 15.00 uur. Voor de theoretische waardebepaling bij uitgifte zijn de slotkoersen en -rentabiliteiten van dinsdag 20 januari 1987 gebruikt.

Op 20 januari 1987 gold het volgende:

- slotkoers van certificaten SR f128,50;

- uitgiftekoers van de LIONS 100;

- gemiddelde effectieve rentabiliteit van staatsobligaties met een resterende looptijd tussen 7 en 10 jaar

$6,09 \%$

\subsubsection{Geen belasting}

Tabel 1 bevat de theoretische waarden van een LIONS op 20 januari 1987

Ten behoeve van de discontering is gebruik gemaakt van de gemiddelde rentabiliteit op staatsleningen met een resterende looptijd van 7-10 jaar, met een opslag van 30 basispunten ter compensatie van het kredietwaardigheids-
Tabel 1: Theoretische koers van de LIONS per 20 januari 1987

(in guldens, marginaal belastingtarief 0\%)

\begin{tabular}{|c|c|c|c|}
\hline \multicolumn{4}{|c|}{ Verwatering: } \\
\hline Waarde zero-coupon gedeelte: & 1077 & 1077 & 1077 \\
\hline Waarde certificaatvergoeding: & 1414 & 1500 & 1592 \\
\hline Waarde dividenden: & & & \\
\hline - groei $0 \%$ & 307 & 330 & 355 \\
\hline - groei $5 \%$ & 373 & 402 & 433 \\
\hline - groei $10 \%$ & 456 & 492 & 530 \\
\hline $\begin{array}{l}\text { Theoretische koers LIONS } \\
\text { (is: Waarde/20): }\end{array}$ & & & \\
\hline - groei $0 \%$ & 109.17 & 112.33 & 115.68 \\
\hline - groei $5 \%$ & 105.88 & 108.73 & 111.78 \\
\hline - groei $10 \%$ & 101.74 & 104.25 & 106.93 \\
\hline
\end{tabular}

risico, resulterend in 6,39\%. ${ }^{17}$ Hierdoor bedroeg de contante waarde van het zero-coupon deel: $f 2000 / 1.0639^{10}=f 1076,52$.

Indien er geen verwatering optreedt zullen gedurende de looptijd van een LIONS in totaal 11 certificaten als vergoeding worden ontvangen (bedenk dat er aan het einde van de looptijd een dubbele vergoeding plaatsvindt). De huidige (markt-)waarde hiervan is $11 \times f 128,50=f 1414,50$.

In het geval van 1\% verwatering per jaar bedraagt het aantal te ontvangen certificaten $\sum_{t=t}^{9}(1,01)^{t}+2 \cdot(1,01)^{10}=11,67$ (afgerond)

De huidige waarde hiervan is $11,67 \times f 128,50=$ $f 1499,78$. In het geval van $2 \%$ verwatering bedraagt deze waarde $12,39 \times f 128,50=$ $f 1591,82$

De contante waarde is uitgerekend onder drie alternatieve veronderstellingen met betrekking tot de dividendgroei (respectievelijk 0, 5 en $10 \%$; voorafgaand aan de emissie bedroeg de jaarlijkse dividendgroei ongeveer $5 \%$ ). Uitgaande van het bekende slot-dividend van $f 3,33$, en interim-dividend $f 2,60$, beide over 1986 , resulteert voor de contante waarde van de niet meegekochte dividendrechten een waarde die ligt tussen $f 307$, - en $f$ 530,-

De theoretische koers van een LIONS is, over- 


\section{MAB}

eenkomstig paragraaf 2.1, bepaald als de optelsom van de contante waarde van het zero-coupon gedeelte en de waarde van de aandelen, verminderd met de contante waarde van de (voor verwatering aangepaste) niet meegekochte dividendrechten. Het resultaat wordt vervolgens door 20 gedeeld (de uitgifteprijs was immers $f 2000,-$, terwijl de uitgiftekoers op 100 is gesteld). Onder alle negen scenario's blijkt de theoretische koers van de LIONS (variërend van 101,7 tot 115,7) aanmerkelijk boven de uitgiftekoers (100) te hebben gelegen.

Voor beleggers zonder inkomstenbelasting verplichting, zoals pensioenfondsen, die gegeven hun portefeuillewensen en institutionele mogelijkheden ruimte hadden voor een aantal LIONS lijkt de uitgiftekoers gunstig te zijn geweest.

De rentegevoeligheid van de LIONS blijkt uit de volgende gegevens: een rentedaling van $0,5 \%$ leidt ceteris paribus tot een waardeverhoging van $\pm 2 \%$, terwijl een renteverhoging van $0,5 \%$ tot een waardeverlaging van $\pm 2 \%$ leidt, anders gesteld: de duration als maatstaf van de rentegevoeligheid is ongeveer 4 .

\subsubsection{Belastingtarief $60 \%$}

Het beeld verandert indien we het geheel bekijken vanuit een belegger die inkomstenbelasting verschuldigd is over de beleggingsopbrengsten. Vanwege het feit dat belasting moest (en moet) worden betaald over de marktwaarde van de te verstrekken certificaten, daalt de waarde van het aandelendeel aanmerkelijk. Uitgaande van een reeds gebruikte rentevrijstelling, wordt $60 \%$ van de waarde op het moment van uitkeren wegbelast, zodat slechts $40 \%$ resteert (overigens is de contante waarde van dat wegbelaste deel iets lager dan hier is uitgerekend omdat te betalen belasting in de regel pas later tot daadwerkelijke uitgaven leidt; vergelijk ook noot 14). Deze marktwaardedaling wordt zoals is te destilleren uit tabel 2, slechts gedeeltelijk gecompenseerd door de lagere contante waarde van de niet meegekochte dividendrechten, en de waardestijging (tot $f$ 1554,-) van de in 1997 belastingvrij te ontvangen hoofdsom; daarbij is uiteraard de disconteringsvoet na belasting gehanteerd. Tabel 2 is overigens onder dezelfde veronderstellingen als tabel 1 opgesteld.

Tabel 2: Theoretische koers van de LIONS per 20 januari 1987

(In guldens, marginaal belastingtarief)

\begin{tabular}{|c|c|c|c|}
\hline Verwa & $\begin{array}{l}\text { tering: } \\
0 \%\end{array}$ & $1 \%$ & $2 \%$ \\
\hline Waarde zero-coupon gedeelte: & 1554 & 1554 & 1554 \\
\hline Waarde certificaat vergoeding: & 566 & 600 & 637 \\
\hline \multicolumn{4}{|l|}{ Waarde dividenden: } \\
\hline - groel $0 \%$ & 140 & 150 & 162 \\
\hline- groei $5 \%$ & 172 & 185 & 200 \\
\hline - groei $10 \%$ & 212 & 229 & 247 \\
\hline \multicolumn{4}{|l|}{$\begin{array}{l}\text { Theoretische koers LIONS } \\
\text { (is: Waarde/20): }\end{array}$} \\
\hline - groei $0 \%$ & 99.00 & 100.17 & 101.46 \\
\hline - groei $5 \%$ & 97.40 & 98.44 & 99.57 \\
\hline - groel $10 \%$ & 95.37 & 96.24 & 97.18 \\
\hline
\end{tabular}

Onder de meeste scenario's was de LIONS niet aantrekkelijk voor de belastingplichtige belegger: de theoretische koers varieert tussen 95,4 en 101,5 (versus de uitgiftekoers van 100). De rentegevoeligheid blijkt lager te zijn dan in het vorige geval. Een rentewijziging van $0,5 \%$ leidt tot een tegengesteld gerichte koerswijziging van iets meer dan $1 \%$

\section{Empirie versus theorie}

Uit de analyse in paragraaf 2 is gebleken dat de theoretische waarde van de LIONS sterk afhankelijk is van de gehanteerde vooronderstellingen. Die vooronderstellingen hebben betrekking op:

- het te hanteren marginaal tarief van de inkomstenbelasting:

- de te gebruiken disconteringsvoet voor de bepaling van de contante waarde van enerzijds de niet meegekochte dividendrechten en anderzijds het zero-coupon deel;

- de toekomstige kapitaalverwatering en het 
effect daarvan op de theoretische koers; - het mogelijk verloop van de toekomstige dividenduitkeringen.

In deze paragraaf gaan wij nader in op het empirisch koersverloop van de LIONS gedurende de reeds verstreken looptijd en zetten deze af tegen de theoretische koers. De gehanteerde vooronderstellingen zijn gelijk aan die in de tabellen 1 en 2. De periode welke in beschouwing wordt genomen begint op 20 januari 1987 en eindigt op 31 december 1992.

De koersgegevens van de LIONS zijn afkomstig uit de Officiële Prijscourant van de Amsterdamse Effectenbeurs. ${ }^{18}$ De dividendverwachting en de verwateringsfactor zijn telkens gebaseerd op de gegevens die op het tijdstip waarvoor de theoretische koers wordt bepaald, bekend waren. Gegevens hieromtrent alsmede die over het exacte tijdstip van betaalbaarstelling (van belang in verband met de discontering) zijn gebaseerd op de jaarverslagen van Stad Rotterdam en afkomstig van Bloomberg Inc. Net als in de tabellen 1 en 2 is met betrekking tot de vereiste rentabiliteit over het zero-coupon deel van de LIONS uitgegaan van een opslag van 30 basispunten over de vereiste rentabiliteit op staatsleningen met een resterende looptijd van 7 tot 10 jaar. Deze gegevens zijn afkomstig van Datastream.

In de figuren 2 en 3 worden boven- en ondergrenzen gepresenteerd, welke het verloop van de maximale procentuele afwijking tonen tussen de theoretische koers (op basis van de scenario's uit de tabellen 1 en 2), en de werkelijke koers. Deze wijze van presenteren vloeit voort uit de keuze voor een scenario-benade- ring; een directe vergelijking van empirische en theoretische koersen is niet mogelijk omdat wij geen eenduidige theoretische koers hebben bepaald (zie paragraaf 2.3). We merken op dat, zoals ook al in de eerder gemaakte berekeningen is gebleken, de in deze figuren getoonde boven- en ondergrenzen overeenkomen met respectievelijk het scenario van laagste dividendgroei/hoogste verwatering en het scenario van hoogste dividendgroei/laagste verwatering. In beide figuren worden de weekgemiddelden getoond (dit heeft onder andere tot gevolg dat er een schijn-

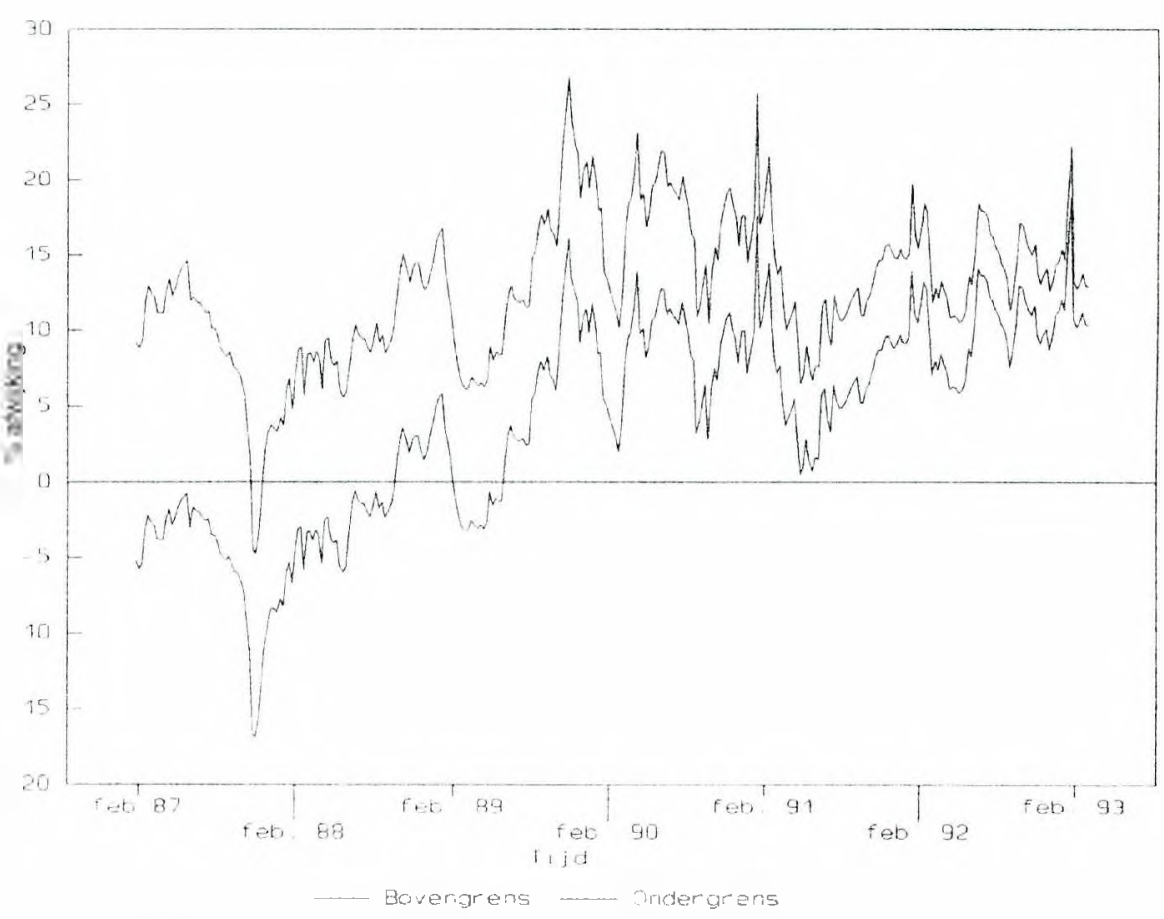

Figuur 2: Boven- en ondergrenzen van de procentuele afwijking ten opzichte van de werkelijke koers, bij een marginaal belastingtarief van $0 \%$

bare afwijking is tussen de resulterende koersen in de tabellen en de beginwaarden van die koersen in de relevante figuren; zie ook noot 18). In figuur 2 wordt uitgegaan van een marginale belastingvoet van $0 \%$, in figuur 3 van $60 \%$.

Uit figuur 2 blijkt dat sedert medio 1989 beide 
grenzen boven 0\% liggen. Bezien vanuit bijvoorbeeld het perspectief van een pensioenfonds met een nul-tarief, impliceert dit, dat vanaf dat moment het werkelijke koersverloop te laag is. Anders gesteld: de LIONS zijn structureel ondergewaardeerd. Dit uiteraard op basis van de gekozen scenario's en de overige veronderstellingen. Het is interessant te zien dat gedurende de crisis op de aandelenmarkt, oktober 1987, de LIONS vanuit dit perspectief overgewaardeerd raakt. Zowel boven- als ondergrens liggen dan beneden de 0\%. Dit effect van de crisis is ook waar te nemen wan- gelmaat wordt overgewaardeerd. Hierbij moet wel worden opgemerkt dat de omvang van de overwaardering, vergeleken met de onderwaardering in figuur 2, beperkt is.

Combinatie van beide figuren doet suggereren dat de koersvorming van de LIONS voornamelijk op basis van handel van de particuliere belegger tot stand komt. Dit wellicht met uitzondering van de koersvorming bij uitgifte, en bepaalde momenten waarop een (institutionele) partij in de markt is verschenen. Dit neemt niet weg dat, zoals reeds eerder werd geconstateerd, de LIONS met name voor pensioenfondsen een aantrekkelijke belegging kunnen vormen.

\section{Afsluiting}

De situatie op de vermogensmarkt, de (fiscale) positie van participanten op die vermogensmarkt en hun 'gedrag', kunnen een aanleiding vormen voor financiële innovatie. In dit artikel is nader ingegaan op een nieuwe vermogensvorm waarvoor geldt dat die aspecten van belang zijn: de hier beschreven LIONS blijkt conceptueel gezien te bestaan uit een aandelendeel en een zerocoupon deel.

Figuur 3: Boven- en ondergrenzen van de procentuele afwijking ten opzichte van de werkelijke koers bij een marginaal belastingtarief van $60 \%$

neer wordt uitgegaan van een marginaal belastingtarief van $60 \%$. De situatie wordt afgebeeld in figuur 3 .

Uit figuur 3 volgt dat de LIONS, vanuit het perspectief van de privé belegger met een marginaal belastingtarief van $60 \%$, met enige re-
De aantrekkelijkheid van een LIONS is sterk afhankelijk van de fiscale status van een belegger. Op een relatief eenvoudige wijze is aangetoond dat een LIONS vooral aantrekkelijk kan zijn voor (institutionele) beleggers die zijn vrijgesteld van belastingheffing. De gehanteerde emissieprijs lijkt aan de lage kant te zijn geweest. Gedurende vrijwel de gehele looptijd van de lening blijkt de marktprijs onder de theoretische waarde te hebben gelegen indien wordt 
geredeneerd vanuit de niet belastingplichtige belegger.

Uit paragraaf 2 blijkt dat theoretisch gezien de koersvolatiliteit van een LIONS afneemt naarmate de resterende looptijd afneemt. Empirisch is deze uitspraak lastig te toetsen omdat enerzijds in de praktijk allerlei verstorende factoren (bijvoorbeeld macro-economische ontwikkelingen) hun invloed kunnen doen gelden, en anderzijds relatief weinig in de LIONS van Stad Rotterdam is gehandeld hetgeen tot gevolg heeft dat de koers gedurende de dagen waarop niet wordt gehandeld vrijwel ongewijzigd blijft. Alleen toegenomen handel in soortgelijke instrumenten zou meer (empirisch) licht op deze zaak kunnen werpen.

Het zero-coupon karakter van het obligatiedeel lijkt uit matching-overwegingen aantrekkelijk voor bijvoorbeeld verzekeringsmaatschappijen en pensioenfondsen. Waarbij moet worden opgemerkt dat het juist een verzekeringsmaatschappij is die de LIONS heeft uitgegeven. Op grond van matching-overwegingen zou men eerder verwachten dat SR juist tot de kopers van zero-coupon obligaties behoort.

De uitgifte van de LIONS-lening van SR is de enige gebleven. Indien we uitgaan van de verwachting dat eventuele nieuwe emittenten de waarde van de te verstrekken certificaten in mindering mogen brengen op hun belastbare winst, moet het mogelijk zijn, met een goede toelichting op de specifieke eigenschappen, en een op specifieke doelgroepen gerichte marketing, meer leningen van dit type te plaatsen; tegen voorwaarden die aantrekkelijker zijn voor de uitgevende instelling dan de voorwaarden als gehanteerd door Stad Rotterdam.

\section{Literatuur}

Allen, F. en D. Gale, 1989, 'Optimal Security Design', The Review of Financial Studies, vol. 1, no. 3.

Assurantieconcern Stad Rotterdam anno 1720 N.V., 1987, Emissieprospectus LIONS 1987 per 1997

Bank for International Settlements, 1986, Recent Innovations in International Banking. Basel.

Barnea, A., R.A. Haugen en L.W. Senbet, 1985, Agency Problems and Financial Contracting. Englewood Cliffs (N.J.): Prentice-Hall.
Dammon, R.M. en R.C. Green, 1987, 'Tax Arbitrage and the Existance of Equilibrium Prices for Financial Assets', The Journal of Finance, vol. XLII, no. 5.

Duffhues, P.J.W., 1990, 'Ontstaan, rubricering en functies van financiële innovaties', in: P.J.W. Duffhues e.a. (red.), Financiële Instrumenten, Moderne Vormen van Financiering en Risicobeheersing, Deventer: Kluwer.

Dybvig, P.H. en S.A. Ross, 1986, 'Tax Cliëtèles and Asset Pricing', The Journal of Finance, vol. XLI, no. 3.

Finnerty, J.D., 1988, 'Financial Engineering in Corporate Finance: An Overview', Financial Management, no. 17 (winter).

Hull, J.C., 1989, Options, Futures and other Derivative Securities, Englewood Cliffs (N.J.): Prentice-Hall.

McConnel, J. en E. Schwartz, 1992, 'The origin of LYONs: A case study in financial innovation', Journal of Applied Corporate Finance (summer).

Merton, R.C., 1992, 'Operation and Regulation in Financial Intermediation: A Functional Perspective', Paper presented at Conference on Operation and Regulation of Financial Intermediaries and Financial Markets, Stockholm School of Economics, Stockholm, Zweden.

Miller, M.H., 1986, 'Financial Innovation: The Last Twenty Years and the Next', Journal of Financial and Quantitative Analysis, vol. 21, no. 4.

Silber, W.L., 1983, 'The Proces of Financial Innovation' American Economic Review, vol. 73, no. 2.

Smid, PP.M., 1991, 'Ontwikkelingen in de theorie van financieringsinstrumenten', in: H. Bergman e.a. (red.), Dossier Corporate Finance, 's-Hertogenbosch: Account

Tempelaar, F.M. en J.M. Overmeer, 1986, 'Perfectie, compleetheid en efficiëntie van de vermogensmarkt; een verkenning van de inhoud en het gebruik van de begrippen in de literatuur', Onderzoeksmemorandum nr. 206 , Instituut voor Economisch Onderzoek, Faculteit der Economische Wetenschappen, Rijksuniversiteit Groningen

Van Horne, J.C., 1985, 'Of Financial Innovations and Excesses', The Journal of Finance, vol. $\mathrm{XL}$, no. 3 .

Walmsley, J., 1988. The New Financial Instruments, Wiley.

Wieman, D. en L.M. van Leeuwen, 1990, 'De LIONS ontleed', VBA Journaal, nr. 2.

\section{Noten}

1 Wij danken prof.dr. J.L. Bouma, prof.dr. F.M. Tempelaar en drs. O Couwenberg voor hun waardevolle op- en aanmerkingen bij eerdere versies van dit artikel. Vanwege dezelfde reden gaat onze dank uit naar de heer W.J. Duinker en drs. M. Buiting van de ABN-AMRO bank. De inhoud blijft uiteraard volledig voor onze verantwoordelijkheid

2 Meer in het algemeen gesteld betreft het zaken als perfectie, compleetheid en (prijs-)efficiëntie van de vermogensmarkt; zie Tempelaar en Overmeer [1986] voor een afgewogen behandeling van deze begrippen. Voor een toelichting op de relatie met financiële innovatie zij ook verwezen naar Duffhues [1990] en Smid [1991]

3 Voor uitgebreide beschouwingen over het verschijnsel financiële innovatie zij verwezen naar bijvoorbeeld Silber [1983], Van Horne [1985], Miller [1986]. Zie tevens Bank for International Settlements [1986], Walmsley [1988] en 


\section{MAB}

Duffhues [1990]

4 Deze LIONS dient niet te worden verward met de LYON (Liquid Yield Option Note) die in 1985 op de Amerikaanse vermogensmarkt is geïntroduceerd. Een LYON is een in aandelen converteerbare niet rentedragende (zero-coupon) obligatie met enkele bijzondere additionele kenmerken. Zie McConnel en Schwartz [1986]

5 Een (markt-)waarde van $f 2000$ - komt overeen met een koers van 100

6 De nieuwe jaaruitkering op enig moment wordt bepaald als het quotiënt van de tot dan geldende jaaruitkering en de urtkomst van de formule: $[(A \times p)+(B \times q)] /[(A+B) \times p]$, waarin $A$ het voor aankondiging van uitgifte van nieuwe aandelen geplaatste nominale aantal gewone aandelen is, $B$ het aantal nieuw uit te geven aandelen, $\mathrm{p}$ de gemiddelde beurskoers gedurende de twintig dagen voor aankondiging en q de uitgifteprijs per aandeel a $f 10$ nominaal. Zie ook blz. 49 van het emissieprospectus

$7 \mathrm{Bij}$ navraag werd echter van de zijde van het emissiesyndicaat gesteld dat de liquiditeitspositie van de emittent geen rol heeft gespeeld in de besluitvorming.

8 Zie Wieman en Van Leeuwen [1990]. Overigens zij vermeld dat de genoemde solvabiliteits- en verwateringsaspecten financieel-economisch bezien geen steekhoudende redenen voor uitgifte zijn.

9 Zie Barnea e.a. [1985] voor een gedegen behandeling van het gebied van de agency costs en hun relatie met financiële innovatie.

10 Hoewel een LIONS, theoretisch beschouwd, relatief eenvoudig is te repliceren dient te worden aangetekend dat ten tijde van de emıssie nog geen verhandelbare zerocoupon obligaties op de Nederlandse vermogensmarkt waren. Voor eventuele replicatie, dan wel arbitrage, zouden onderhandse transacties nodig zijn geweest. Dergelijke transacties gaan in de regel gepaard met relatief hoge kosten. De LIONS is daarmee een nieuw produkt omdat transactiekosten kunnen worden bespaard

11 De waarde ( $f$ ) van een termijncontract op een aandeel waarop dividend wordt uitgekeerd kan als volgt worden bepaald: $f=S-\mid-K \cdot e^{(\{T-1)}$

S symboliseert de huidige waarde van het aandeel, I is de contante waarde van de, gedurende de looptijd uit te keren, dividenden en $\mathrm{K}$ is de termijnprijs. De risicovrije rentevoet op jaarbasis wordt weergegeven door $r$. T symboliseert de afloopdatum van het contract en $\mathrm{t}$ is het huidige tijdstip. Omdat de termijnprijs in het onderhavige geval nihil is, is $f$ simpel te bepalen als S-I. (Zie Hull [1993, blz. 54]).

12 De onderhavige analyse ziet af van de waarde van het zeggenschapsrecht, hetgeen is te verantwoorden, omdat het hier certificaten van aandelen betreft.

13 Uiteraard is in zijn algemeenheid meer te zeggen over de gevoeligheid van de waarde van de LIONS voor wijzigingen in de waardebepalende parameters. In dat verband blijken de rente-elasticiteit en de aandeel-elasticiteit in samenhang met de resterende looptrjd van belang te zijn. Ten behoeve van een analytische ontleding van een LIONS (niet specifiek die van Stad Rotterdam maar nu gezien als beleggingsinstrument in het algemeen) kan bijvoorbeeld gebruik worden gemaakt van de methode van de comparatieve statica en/of stochastische simulatie technieken. Een publikatie die dergelijke analyses bevat is in voorbereiding. $14 \mathrm{Wij}$ beseffen dat het hoogste marginale tarief destijds $72 \%$ bedroeg. Het door ons gehanteerde percentage van $60 \%$ kan desgewenst worden geïnterpreteerd als het verwachte belastingtarief; de discussie over een verlaging van het toptarief was ten tijde van de emissie immers al in volle gang. Het relevante percentage had dus nog hoger kunnen zijn hetgeen echter de resultaten slechts had versterkt (dit geldt evenzo voor de resultaten in paragraaf 3 ).

15 Daarbij is impliciet uitgegaan van de veronderstelling dat de verwachte kapitaalverwatering reeds in de huidige aandeelprijs is vervat.

16 De theoretische waarde van een beleggingsinstrument komt tot stand vanuit een opportunity-cost gedachtengang wat zouden beleggers op dit moment willen betalen voor de in het vooruitzicht gestelde (onzekere) kasstromen die via aanschaf van het instrument zullen worden verkregen. Daartoe vergelijken zij uiteraard het onderhavige beleggingsinstrument met equivalente beleggingsmogelijkheden. De prijs die ze willen betalen (het 'zekerheidsequivalent'), in samenhang met de verwachte kasstromen bepalen de impliciete rentabiliteitseis; deze is uiteraard hoger dan de risicovrije indien er (systematische) onzekerheden kleven aan het beleggingsinstrument

17 Alternatieven, zoals de gemiddelde vereiste rentabiliteit over de 5 langstlopende staatsleningen, leiden, gegeven de beperkte rentegevoeligherd van de theoretische waarde van de LIONS, niet tot gewijzigde conclusies.

18 Daarbij dient te worden aangetekend dat de omzet in de LIONS gedurende de beschouwde periode beperkt is gebleven, hetgeen de 'betrouwbaarheid' van de empirische noteringen doet verminderen. Doordat wij hebben gewerkt met weekgemiddelden worden naar onze mening de daaruit voortvloeiende problemen voldoende ondervangen; ze tasten de kern van ons betoog niet aan. 